\title{
QUEEN'S
UNIVERSITY
BELFAST
}

\section{Tackling Crime and Paramilitary Violence: Present Day Challenges for Community-Based Restorative Justice Projects}

Hogg, L., \& Butler, M. (2018). Tackling Crime and Paramilitary Violence: Present Day Challenges for Community-Based Restorative Justice Projects. British Journal of Criminology, 58(3), 689-708. https://doi.org/10.1093/bjc/azx056

\section{Published in:}

British Journal of Criminology

\section{Document Version:}

Peer reviewed version

Queen's University Belfast - Research Portal:

Link to publication record in Queen's University Belfast Research Portal

\section{Publisher rights}

(c) 2017 The Author. Published by Oxford University Press on behalf of the Centre for Crime and Justice Studies (ISTD).

All rights reserved. This work is made available online in accordance with the publisher's policies. Please refer to any applicable terms of use of the publisher.

\section{General rights}

Copyright for the publications made accessible via the Queen's University Belfast Research Portal is retained by the author(s) and / or other copyright owners and it is a condition of accessing these publications that users recognise and abide by the legal requirements associated with these rights.

Take down policy

The Research Portal is Queen's institutional repository that provides access to Queen's research output. Every effort has been made to ensure that content in the Research Portal does not infringe any person's rights, or applicable UK laws. If you discover content in the Research Portal that you believe breaches copyright or violates any law, please contact openaccess@qub.ac.uk. 
In the almost 20 years since the Good Friday Agreement, much progress has been made. Levels of paramilitary violence are greatly reduced, there is cross-political party support for policing and many of the criminal justice institutions have been transformed (Chapman 2012; Archick 2017). Nonetheless, challenges remain. Northern Ireland continues to experience political division, community tensions and paramilitary violence (Archick 2017). Statistics indicate that paramilitary related bombings, shootings and assaults remain at just under one third of their 1990's levels and paramilitaries continue to be involved in crime, including assault, intimidation, robbery, fraud, smuggling, drug dealing, extortion and murder (Tonge 2014; NIO 2015; PSNI 2016). Many paramilitary organisations are also fragmented, such that even if paramilitary leadership advocate a discontinuation of crime and violence, local paramilitary members vary in their willingness to disengage from these activities (NIO 2015). In response, the Northern Ireland government has reiterated its commitment to using restorative justice and the voluntary and community sector to help reduce crime and paramilitary violence (NIE 2016a; 2016b). This article focuses on the work of community based restorative justice projects to examine their ability to address crime and paramilitary violence in present day Northern Ireland.

While much has been written about community based restorative justice projects, little is known about how increasing state regulation has affected their ability to use restorative justice to address crime and paramilitary violence. This article makes an original contribution to this literature by critically examining if changing State policies has helped or hindered the ability of these projects to use restorative justice to reduce crime and paramilitary violence. The article begins by briefly describing the establishment of these projects and how they have evolved. Next, the research methodology is described and the findings are presented. It is argued that both State agencies and paramilitaries constrain the projects use of restorative justice to situations which are acceptable to them. While State officials appear to control project work to ensure this work complements rather than competes with State agencies, paramilitary members seek to avoid projects interfering with their criminal endeavors or weakening their influence over local communities. These findings raise 
questions about the extent to which efforts by State agencies to control and regulate the use of restorative justice may actually undermine its ideology and effectiveness, as well as the likely success of the Northern Ireland government's plans to reduce paramilitary crime and violence.

\section{$\underline{\text { Restorative Justice and Community Based Restorative Justice Projects }}$}

Restorative justice is difficult to define as it refers to a wide range of practices, with different theoretical approaches used to explain these practices (Marshall 1999; Crawford and Newburn 2003; Johnstone 2003). One definition that has been widely quoted defines restorative justice as "a process whereby all the parties with a stake in a particular offence come together to resolve collectively how to deal with the aftermath of the offence and its implications for the future" (Marshall 1999: 35). Accordingly, restorative justice is generally presented as representing a different way of thinking about crime and responding to it (Van Ness and Strong 1997; Johnstone 2003). Unlike the conventional criminal justice system, the primary focus of restorative justice is on the harm caused by crime and repairing this harm rather than administering punishment in response to law-breaking activity (Zehr 1985; Graef 2001). In this way, restorative justice seeks to encourage offenders to repair the harm they have caused and prevent re-offending by encouraging offenders to take responsibility for their actions (Van Ness and Strong 1997).

Some contend that restorative justice offers a more constructive way of responding to crime than the conventional criminal justice system (Morris 2002; Johnstone 2003). In the criminal justice system, crime is viewed as an offence against the State, with the State (via State officials) deciding how best to respond to law-breaking behaviour (Zehr 1985; Braithwaite 2002). In contrast, restorative justice tends to perceive crime as an interpersonal harm occurring between individuals instead of a violation of an abstract law (Zehr 1985; Johnstone 2003). Restorative justice argues that rather than relying entirely upon the criminal justice system and criminal justice professionals to manage crime, those affected by crime should participate in defining and resolving their own crimes (Johnstone 
2003). Restorative justice, therefore, seeks to empower victims, offenders and communities to take ownership over responding to crime and gives primacy to the needs and interests of those most affected (Morris 2002).

In order for practices to be credibly perceived as 'restorative', Johnstone and Van Ness (2007) have argued that they must incorporate the following six attributes. Firstly, they should include informal discussions about crime, the harm caused and a way forward. These discussions should aim to involve victims, offenders and others connected to the criminal event. Secondly, the focus should be on empowering people who have been affected by crime. Thirdly, accepting responsibility and making amends for criminality should be encouraged rather than punishing or stigmatising offenders. Fourthly, discussions need to be guided by the values of equality, respect and inclusivity, to avoid proceedings being dominated by any one stakeholder. Fifthly, time should be devoted to discussing the harms caused to victims, their needs and how these harms can be repaired. Finally, these discussions should focus on resolving conflicts and rebuilding/strengthening relationships. Johnstone and Van Ness (2007) maintain that only those practices which encompass all six attributes can be truly labelled as 'restorative'. If practices only incorporate some but not all of these attributes, they "could, at best, be described as 'partly restorative'" (Walters 2014: 129). In Northern Ireland, community based restorative justice projects have sought to adopt these attributes as far as is possible in their work with victims, offenders and community residents (Chapman 2012).

Since community based restorative justice projects began to emerge, they have garnered international attention due to their role in conflict transformation, peace building and community safety (McEvoy and Mika 2001; 2002; Mika 2006; Shirlow and McEvoy 2008; Eriksson 2009). In Northern Ireland, community based restorative justice projects arose from a desire within communities to reduce paramilitary punishment violence, which was used to punish/deter crime and anti-social behaviour (McEvoy and Mika 2001; Monaghan 2010; Knox 2013). Paramilitary punishment violence typically involves those accused (or their families) of crime/anti-social behaviour being 
intimidated, threatened, excluded, physically beaten or shot in order to 'persuade' them to desist from wrongdoing (McEvoy and Mika 2001). Due to the conflict in Northern Ireland, many people living in working-class Protestant and Catholic communities were distrustful of State agencies and reluctant to seek help from State officials (Ellison and Smyth 2000; Byrne and Monaghan 2008). This reluctance and distrust created a governance gap which paramilitaries began to fill (McEvoy and Mika 2001). While some community members encouraged paramilitaries to take on this role, adopting this 'policing' function also helped paramilitaries to cement their power and influence over these communities (Cody 2008). However, the use of paramilitary punishment violence led some to seek an alternative, non-violent, community response to crime and anti-social behaviour (McEvoy and Mika 2001).

As a result, two community based restorative justice organisations were established in 1998 , initially funded by a US charitable foundation (Mika 2006). These organisations were called Community Restorative Justice Ireland (CRJI) and Northern Ireland Alternatives (NIA) and established community based restorative justice projects in a number of areas throughout Northern Ireland (Eriksson 2009). CRJI projects operated within working class Catholic areas and NIA projects operated within working class Protestant areas (Eriksson 2009). These projects sought to work directly with paramilitaries to promote and provide a non-violent, lawful alternative to paramilitary punishment violence (McEvoy and Mika 2001). CRJI predominately worked with the Provisional Irish Republican Army, while NIA mostly worked with the Ulster Volunteer Force (McEvoy and Mika 2001; Eriksson 2009). While restorative justice was not an organising principle of the work of the projects during their establishment, it subsequently became an explicit guiding focus of both organisations (McEvoy and Mika 2002; Eriksson 2009).

CRJI and NIA projects worked with individuals who were threatened with paramilitary punishment violence in areas that were mostly distrustful of State officials (McEvoy and Mika 2001; Eriksson 2009). With the cooperation of paramilitary members, alleged offenders, victims and local 
residents, these projects sought to avert the use of paramilitary punishment violence by encouraging paramilitary members to defer those accused of wrongdoing to their projects (McEvoy and Mika 2001). As an alternative to paramilitary punishment violence, these projects sought to use restorative justice to encourage desistance (McEvoy and Mika 2001). Through a series of meetings, discussions and/or conferences, project staff attempted to work with local residents, paramilitary members, victims and alleged offenders, to encourage alleged offenders to take responsibility for their actions and repair the harm that they had caused (Eriksson 2009). However, not all paramilitary organisations agreed to work with these projects, and amongst those that did, they tended to filter which cases the projects could intervene in (McEvoy and Mika 2001). While paramilitaries were generally amenable to intervention in cases involving young people, the projects were not usually allowed to intervene in cases involving paramilitary members, sexual offences, paramilitary interfactional disputes and/or the sale of drugs (Winston 1997; McEvoy and Mika 2001; 2002). During this time, CRJI and NIA projects were independent of State agencies, with their non-State funding enabling this independence. The community nature of these projects and their independence from State agencies was believed to be key to their ability to encourage paramilitary members, alleged offenders, victims and local residents to buy into their work (McEvoy and Mika 2001).

Research conducted at this time indicates that these projects played a positive role in reducing paramilitary punishment violence (Mika 2006). Between 1999 and 2005, the projects prevented almost 500 cases of paramilitary punishment violence (Mika 2006). These projects were also credited with facilitating conflict transformation and the reintegration of former paramilitary members (Shirlow and McEvoy, 2008; Eriksson 2009). Nevertheless, some commentators were worried about the potential power, control and influence that paramilitary organisations may retain over the projects (Criminal Justice Review 2000; see McEvoy and Mika 2001). Concerns were also expressed that local residents may feel coerced into engaging with the projects due to the employment of some former paramilitary members as project staff (see McEvoy and Mika 2001) 
These concerns led the State to change their policies towards the projects so as to increase their oversight and regulation of these projects, as well as their own use of restorative justice. The State extended their use of restorative justice for dealing with youth crime in 2003, following recommendations from the Criminal Justice Review (2000) and the Justice (Northern Ireland) Act 2002 (Campbell et al. 2005). The Youth Justice Agency was tasked with using restorative justice to deal with youth offending.

Meanwhile, a protocol outlining a process by which projects could receive State funding, collaborate with State agencies and act as a formal restorative justice disposal within the criminal justice system was introduced in 2007 (NIO 2007). While some aspects of this protocol (e.g. eligibility for State funding) were welcomed, other aspects were not (Chapman 2012). As part of the protocol, projects were subject to certain constraints, one of which involved project staff reporting all known crime to the police and waiting for the Public Prosecution Service to decide what role, if any, they could play in responding to crime (NIO 2007). Only cases involving youth crime were generally considered eligible for the protocol as, from the projects establishment, paramilitaries were generally only amenable to project intervention in cases involving youths (McEvoy and Mika 2001; Knox 2002). Under the protocol, the Public Prosecution Service must formally refer a case to the projects for disposal before they are allowed directly respond to crime. As part of the protocol, the projects could also apply for State funding, if their practices were independently inspected and verified (NIO 2007). If the projects agreed to the protocol and passed the independent inspection, they were deemed to be State accredited. This State accreditation allowed State officials to formally share information and collaborate with the projects, sanctioned their use as a restorative justice disposal in the criminal justice system and ensured their eligibility for State funding.

Both CRJI and NIA decided to agree to the conditions of the protocol and became State accredited projects as the political context in Northern Ireland had changed, key criminal justice institutions had been reformed and non-State sources of funding were reducing (Chapman 2012; Knox 
2013). The introduction of the protocol led to closer working relationships with State officials and these projects have been credited with helping to reduce crime and anti-social behaviour through their crime prevention, diversionary and community safety activities (O'Dwyer and Payne 2016). Yet, the use of restorative justice to deal with youth crime by both the projects and the Youth Justice Agency has led to concerns that the Public Prosecution Service may prefer to refer cases to the Youth Justice Agency over the projects (O'Dwyer and Payne 2016). Suspicions have been expressed that the projects use of restorative justice has lessened since the introduction of the protocol (Chapman 2012; Chapman et al. 2016). Consequently, some are worried that the State is using these projects to complement State services rather than allow the projects to play a direct role in addressing crime and paramilitary violence (Chapman 2012).

There are also concerns that these developments may have weakened the willingness of paramilitary members and local residents to work with these projects, as well as changed the type of work the projects are engaged in (Chapman et al. 2016). Some researchers have argued that the protocol has weakened the ability of the projects to respond to local crimes, as well as dis-incentivised engagement between the projects, paramilitary organisations and local residents (Eriksson 2009; Chapman 2012). Nevertheless, little is known about how these events have actually affected the workload of the projects, relationships with paramilitaries and local residents or the use of restorative justice. This gap in our knowledge needs to be addressed if our understanding of how State policies may affect community restorative justice initiatives and the potential of such initiatives to reduce crime and paramilitary violence is to be improved.

\section{The Present Study}

This paper seeks to examine if changing State policies, encouraging greater State regulation (via the introduction of the protocol and State funding) has affected the ability of State accredited community based restorative justice projects to use restorative justice to address crime and paramilitary violence. 
Exploring this issue is particularly important as the Northern Ireland government has placed community projects and restorative justice initiatives at the centre of its plans to end paramilitary violence and crime (NIE, 2016a; 2016b). Reflecting on the experience of these projects may, therefore, provide useful insights into how effective practices in this area may be strengthened and developed, while also identifying what obstacles may need to be overcome if the ability of these projects to lessen paramilitary violence and crime are to be enhanced. Moreover, the experience of Northern Ireland may offer useful insights into the tension between State efforts to regulate the use of restorative justice, the needs of communities and how efforts to negotiate these tensions may result in processes which undermine the potential benefits of restorative justice.

\section{Methodology}

This research employed a mixed methods approach, consisting of a participant observation, in-depth semi-structured interviews and a review of available administrate data. Ethical approval for the study was obtained from Queen's University Belfast.

\section{Participant Observation}

A six-month participant observation of one State accredited project was undertaken to examine the workload of the project and the challenges project staff encountered. Detailed field notes were used to identify emerging patterns and themes, and inform the questions asked during the interviews. The exact location of the project is not revealed in order to protect the anonymity of participants. The first author was familiar with the community in which the observations were conducted and had previously volunteered with the local project for three years. This familiarity facilitated access to the research 
field. However, the author ceased volunteering with the project four months prior to data collection to delineate between their role as a volunteer and a researcher.

Interviews

A total of thirty-nine interviews were conducted. This included: eight with staff working in projects in Protestant areas; eleven with staff working in Catholic areas; ten with representatives from a range of State agencies including the PSNI, the Youth Justice Agency, the Public Prosecution Service, the Department of Justice and the Department of Social Development (renamed as the Department for Communities); four with the voluntary and community sector; two with community representatives and four with individuals whose work brought them into frequent contact with the projects. The interview sample was purposeful, with interviewees deliberately chosen due to their profession, knowledge and familiarity with the topic. In-depth semi-structured interviews were used, with interviews lasting approximately forty-fix minutes. Conducting interviews enabled more detailed information on specific aspects of the projects work to be elicited, as well as their use of restorative justice, funding and interactions with State officials, paramilitary members and local residents. Interviews were audio-recorded, transcribed and entered into NVivo for analysis. To protect anonymity and confidentiality, specific details about the interviewees are not provided.

\section{$\underline{\text { Administrative Records }}$}

Available administrative records were also examined. The case histories of those referred to the project in the participant observation were reviewed to examine how many criminal cases the project dealt with pre and post the implementation of the protocol, as well as their records of the activities they were involved in delivering during the participant observation. Information about the funding for 
this project was also obtained. Additionally, the number of protocol referrals made throughout Northern Ireland were examined.

\section{Data Analysis}

Thematic analysis was used to analyse the participant observation and interview data. This form of analysis was chosen due to its flexibility and ability to provide a rich and detailed analysis of emerging themes (Braun and Clarke 2006). Due to the quantity and quality of the available administrative records, it was not possible to undertake statistical analysis of this data but frequency counts are reported. Data triangulation was also used to assess whether what was observed in practice reflected what was officially recorded in the administrative records and the interviews.

\section{Findings}

The findings are divided into three sections. The first section investigates the impact of the protocol on the number of criminal cases referred to the projects and their use of restorative justice. The second section examines how State funding has shaped the work of the projects, paying particular attention to their ability to undertake activities which directly address crime, paramilitary violence and restorative justice. The third section explores how the introduction of the protocol has affected relationships between project staff, paramilitaries and local residents, influencing the extent to which these groups are willing to cooperate with project staff to allow them to play a role in responding to crime and paramilitary violence.

\section{The Protocol and Its Impact on Referrals and Restorative Justice}


A review of the administrative records of the project in the participant observation revealed that referrals from paramilitary members and local residents had diminished following their decision to sign up to the protocol and become a State accredited project. Prior to its State accreditation, the project had received forty-two referrals of youth crime from family members, paramilitary members, offenders and local residents but none were recorded as being received following their State accreditation. In addition, the project did not receive any protocol referrals from State agencies, which meant they had never been allowed to use restorative justice to deal with crime, despite their inclusion in the criminal justice system as a restorative justice disposal. The experience of this project was not unique, as a review of all protocol referrals throughout Northern Ireland revealed that only ten cases were referred to the projects for a restorative justice disposal by the Public Prosecution Service over a seven year period.

Project staff believed that the number of referrals that were initially envisaged under the protocol "never really materialised" (participant 29) because policymakers had little knowledge about the realities of living and working in an area with a strong paramilitary presence and did not appreciate how the requirement to report all known crimes to the State would be reacted to by paramilitary members and local residents:

"That's alright to set protocols, people who are up in the higher echelons of power [...] but once you come onto the ground and live in the real world it is completely different" (participant 19).

In contrast, State officials claimed that these requirements needed to be included in the protocol in order to build State confidence in the work of the projects and reassure State agencies and the wider public that project staff were "people who were capable of doing this work and that they were people who had the right motivations" (participant 23). This implies that, at the time the protocol was first introduced, State officials viewed the protocol primarily as a means of validating the credentials of 
project staff and monitoring their work, rather than as a mechanism for creating an effective partnership to tackle crime and paramilitary violence.

When asked why so few cases had been referred under the protocol, State officials and project staff tended to blame each other. One State official stated:

"It is not a policy decision on behalf of police or Public Prosecution Service that cases aren't being dealt with by the projects [...] it's really a practical reason that there hasn't been referrals [...] the information dried up" (participant 28).

In contrast, project staff tended to state:

"Because we've got the Youth Justice Agency, so I think having that maybe deters a little bit away from the protocol because there's a statutory sort of agency there that deals with all of those, so it [referring cases to the Youth Justice Agency for a restorative justice disposal] just seems to be automatic" (participant 5).

From reviewing the administrative data, both these perspectives appeared to have some validity. Throughout Northern Ireland, only sixteen criminal cases had been officially recorded as being referred from the projects to the Public Prosecution Service (via the police) under the protocol since its introduction. Ten of these cases had been referred back to the projects for a restorative justice disposal. However, the Public Prosecution Service can refer any case of low level crime to the projects, if they believe a restorative justice disposal may be appropriate. The fact that the Public Prosecution Service had referred between 538 and 768 cases of youth offending to the Youth Justice Agency for a restorative justice disposal (DOJ 2013; 2016), during the same timeframe as it had referred ten cases to the projects, reinforced a perception of bias towards the Youth Justice Agency. Consequently, while the records suggested that the projects seldom reported cases to the police under the protocol, it also indicates that the Public Prosecution Service rarely used the projects as a restorative justice disposal, preferring instead to refer cases to the Youth Justice Agency. 
Project staff justified the low number of protocol cases reported to the police by explaining that local residents, offenders and paramilitaries were less likely to report crimes to them following the decision by the projects to become State accredited. This claim was supported in the review of the administrative records of the project in the participant observation. As previously reported, this project had recorded forty-two criminal referrals from local residents, offenders, family members and paramilitaries prior to their State accreditation, while no incidents were recorded following their accreditation. Yet, this explanation only partly explains these events as, from the participant observation, it became apparent that project staff did not always report crimes to the police, and crimes that were reported to the police were not always recorded as protocol cases. During the participant observation, project staff used their discretion in deciding when to report crimes to the police. While the majority of crimes were not reported because project staff were unsure who exactly had committed the crime, in other cases crimes were not reported as to do so would place witnesses, victims and offenders at risk of violent retaliation by paramilitary members. Indeed, such an incident was observed during the participant observation (see the section on relationships with paramilitaries and local residents for a more detailed discussion of this issue). When projects did report crimes to the police, these crimes were not always recorded as protocol cases by either project staff or State officials. Such an incident was witnessed during the participant observation. From this incident, it seemed that the infrequent use of the protocol had resulted in project staff internalising the belief that "we aren't allowed to work with the [criminal] act" (participant 1), with the result that they no longer requested that such crimes were dealt with under the protocol. Interviews with State officials also implied that the infrequent use of the projects as a restorative justice disposal (last used in 2012) led some to be unfamiliar with the potential for the projects to be used in this manner. This raises the possibility that while the projects can officially be used as a restorative justice disposal in the criminal justice system, in practice its infrequent use had resulted in some professionals either forgetting about this disposal mechanism or no longer considered it to be a likely option. 
Some State officials suggested that the likelihood of the Public Prosecution Service referring cases to the projects was reduced because the police and Public Prosecution Service now had a greater range of disposals and means of delivering these disposals to choose from:

"Eight years ago, the number of alternatives to prosecution that were really open to the Public Prosecution Service, were really three; informed warning, caution and diversionary youth conference [with the Youth Justice Agency]. [...] [Now] There is more competition in this market [...] which is a negative for community based restorative justice groups because back in 2007, there weren't many competitors" (participant 28).

Other State officials defended the use of the Youth Justice Agency to deliver restorative justice over the projects by questioning the ability of project staff to undertake restorative justice and stating that they were duplicating a service already provided by the Youth Justice Agency:

"[Project staff] would say they mediate by going to the paramilitaries and negotiating that a young person remains in the community and going back to the young person and their family. Mediation, which is I suppose [is] on the continuum of restorative practice, but I haven't heard of any evidence of any kind of restorative conferences, or face-to-face meetings between victims, people who have done wrong and those who have been affected by it, so it is very different" (participant 15).

"If they were offering different things [...] rather than going to repeat the same thing that Youth Justice Agency are doing" (participant 6).

Project staff tended to counter such views by arguing that they were better placed to carry out restorative justice as their community knowledge and relationships with local residents were stronger than those of State officials and, as a result, they could elicit greater engagement from victims, offenders and community members. They also stated that they had been trained in delivering restorative justice and were only allowed to engage in restorative justice conferences if cases were 
referred to them by the Public Prosecution Service. As the last case referred to the projects for a restorative justice disposal was in 2012, they argued that the State had not allowed the projects to act as a restorative justice disposal for criminality in recent years.

In criminal cases which were not reported to the police (due to a lack of certainty over the offender's identity and/or the potential dangers doing so may pose for victims, witnesses or offenders), project staff did attempt to use restorative justice in amenable situations. These cases predominately involved paramilitary activity, with project staff attempting to mediate between paramilitary members, victims, witnesses and offenders, and working with young people involved in crime and/or antisocial behaviour by providing them with one-to-one support. This work was described by one respondent as forming "less than ten per cent" (participant 29) of the projects workload following the introduction of the protocol, in comparison to their focus solely on this work when they were initially established. This claim was supported in the review of the administrative records of the project in the participant observation. From being predominately focused on trying to reduce paramilitary punishment violence, mediate between paramilitary members and local residents and work with those involved in crime/antisocial behaviour when initially established, the project was now mostly involved in crime prevention, community safety and youth work. While previously the project had been funded by non-State sources to work on crime and paramilitary related cases, during this research the vast majority of the project's funding was provided by State agencies, who were funding the project to provide general crime prevention, community safety, youth work and diversionary services rather than directly address crime or paramilitary violence.

\section{How State Funding has shaped Project Workloads}

During the research, while the Department of Justice provided some funding to the projects, this funding was generally used to fund central administrative functions and was dwarfed by the funding provided by the Department of Social Development, renamed as the Department for Communities. 
Local project offices and project staff were mostly funded by the Department for Communities, with additional funding provided by other State agencies (e.g. the police, local councils or the Housing Executive) for specific programmes. As part of this funding, projects were required to focus on "more preventative and community safety" (participant 13) activities rather than deal directly with crime or paramilitary activity as this was seen as falling under the responsibility of the Department of Justice:

"[Department for Communities] only funded, and it was a big stipulation at the time [...] nonprotocol work, purely because on the basis of departmental segregation, protocol work was seen as being the responsibility of the Northern Ireland Office [...] and then [...] Department of Justice so it was more of, that sort of split" (participant 3).

The reality of this funding meant that project staff spent most of their time delivering general crime prevention, community safety and other such work, in order to meet the targets set by the Department for Communities and other State funders, rather than being focused on crime and paramilitary violence. Indeed, many of these funding arrangements prohibited project staff from discussing criminal offences with those using their services, unless a case had been specifically referred to them for a restorative justice disposal by the Public Prosecution Service:

"We [project staff] are only allowed to work with their other issues. [...] So we were looking at their drug use and their alcohol use and their family support and what was going on in their own lives, but we aren't allowed to talk about the issue of the crime" (participant 1).

Restrictions prohibiting the discussion of crime by the funders meant that, according to Johnstone and Van Ness's (2007) six attributes of restorative justice, most of the current workload of the projects could be considered as being 'partly restorative' rather than 'truly restorative' in nature.

In the interviews and participant observation, the benefits of providing general community safety, crime prevention, youth work and diversionary services was acknowledged but concern was 
expressed that providing these services was distracting projects from their original aim of using restorative justice to address crime and paramilitary violence:

"You move away from the core ethos of what an organisation is supposed to be doing, and they get channelled down through everyone else's wants and desires then it damages what the purpose was in the first place" (participant 8).

Some felt these developments had been intentional as they believed State officials wanted to retain their ownership and control over crime and justice issues:

"I think that the government wants to keep control of everything" (participant 1).

These participants argued that if criminal cases were referred to the projects for a restorative justice disposal, it would challenge the dominance of State officials and their use of restorative justice. It was for this reason, some respondents felt that the projects were being manoeuvred away from using restorative justice to deal with crime and paramilitary violence:

"[The current work of the projects] ... is inching them away from restorative justice, because that's where the State is threatened" (participant 20).

State officials, on the other hand, tended to attribute these developments to a desire to avoid a duplication of services and to have a coordinated approach to responding to crime. They also perceived the projects as providing a valuable contribution to sharing intelligence, preventing people becoming involved in crime and supporting those affected by crime/anti-social behaviour rather than directly responding to criminality. This was reflected in the services they funded the projects to undertake. State officials were able to significantly shape the workload of these projects by dictating what tasks they are expected to deliver in their funding contracts and controlling their use of restorative justice through the protocol.

Of course, the projects voluntarily subjected themselves to this increased State regulation as they chose to sign up to the protocol and apply for State funding. However, it was argued by project 
staff that the diminishing availability of alternative non-State funding sources disadvantaged the projects and placed them in a position in which they felt they had had little option but to submit to this increased State regulation, if they were to continue to operate.

"If you are not playing ball we will just embargo all [project] funding then. And that's what [State agencies] did. And that's the power they exuded on [the projects]. They embargoed all the funding. [Projects] couldn't apply for any funding until the protocol was in place" (participant 11).

These actions had a number of consequences for relationships between the projects, local residents and paramilitary members, which in turn added to the challenges project staff face in trying to address crime and paramilitary violence.

\section{$\underline{\text { Relationships with Paramilitaries and Local Residents }}$}

While historically there had been significant cooperation between the projects and some paramilitary organisations, the interviews and observations indicated that this level of cooperation was no longer as reliable as it once was and varied across organisations, time and location. One participant summed up the situation by stating that, "some members of paramilitary organisations are willing to work with us [projects]. Others are not" (participant observation). A number of explanations were offered to explain this including: the nature of the alleged offence; characteristics of the alleged offender; continued involvement of some paramilitaries in an armed struggle for a United Ireland; the decision by the projects to become State accredited; relationships between local project staff and local paramilitary members; and an increasingly fragmented paramilitary leadership. The influence of some of these factors was evident from the establishment of the projects, with paramilitary organisations varying in their willingness to work with the projects and filtering what cases they allowed the projects 
to intervene in. Others, however, appeared to be linked to events that had occurred since the introduction of the protocol.

Prior to the introduction of the protocol, the varying willingness of paramilitaries to cooperate with the projects hindered their ability to use restorative justice to tackle crime and paramilitary violence. In Catholic areas, armed Republican paramilitaries who had not signed up to the peace process and who were not on ceasefire continued to be the least likely to cooperate with project staff. These paramilitary members were continuing to engage in paramilitary punishment violence and were usually disinterested in efforts to resolve incidents using non-violent means:

"The armed groups, why would they want non-violent? [...] Some of them might, or some of them might in some cases, but they obviously reserve the right then to disengage if that's what they want to do" (participant 33).

Likewise, in Protestant areas, paramilitary members who were willing to work with the projects continued to filter cases which they allowed project staff to intervene in. However, the effects of an increasingly fragmented paramilitary leadership was also evident within these areas.

During the research, local paramilitary members in Protestant areas varied in their willingness to cooperate with project staff, even when their central leadership were encouraging such cooperation. Participants recounted how a change in the local leadership of a paramilitary group in one particular Protestant area, altered the willingness of local paramilitary members to engage with project staff. Despite a history of working together to reduce crime and violence, interactions became more sporadic, unreliable and local paramilitary members were no longer as willing to listen or engage with project staff as they once were. Local project staff felt that these paramilitary members were expressing a "sort of bravado or attitude where we will do what we want to do and nobody will tell us what to do" (participant observation). This resulted in minimum interactions and engagement between these paramilitary members and project staff, with project staff being told to "mind their own business" (participant observation) when they attempted to intervene in incidents involving 
paramilitaries. This left some project staff feeling "we are not doing what we were set-up to do, we are not an alternative [to paramilitary punishment violence]" (participant observation).

Following the introduction of the protocol, paramilitary members continued to be involved in selectively policing alleged wrongdoing. While paramilitaries took action to address the alleged wrongdoing of those from the local area and those who were not a member of their paramilitary organisation, they did not appear to hold their own members to account in the same way. This was evident prior to the introduction of the protocol by paramilitary organisations declining to allow project staff to intervene in cases involving paramilitary members, paramilitary interfactional disputes, sexual offences or the sale of drugs. From the participant observation and interviews, it was evident that a number of paramilitary members continued to be involved in criminal activities and were reluctant to allow project staff to interfere in these endeavours. Although this had been the case prior to the protocol, the requirement to report all known crime to the police further dis-incentivised paramilitary involvement with the projects and, in many cases, actively discouraged it as paramilitary organisations in both Catholic and Protestant areas did not want the police to be informed of their activities.

Consequently, the introduction of the protocol, and the development of closer working relationships between project staff and State officials, was believed to have deterred paramilitary members and their supporters from engaging with project staff and, in some cases, contributed to project staff being threatened by paramilitary members. From the participant observation, it appeared that project staff could undertake work which did not affect paramilitary members or paramilitary actions but if project staff sought to challenge paramilitary members or their endeavours, they could be threatened. Throughout the research, accounts of project staff being intimidated, labelled as 'touts' and offices being vandalised were heard. Accordingly, within present-day Northern Ireland, concerns about State accredited project staff being "community workers by day and paramilitaries by night" were not substantiated by this research, as these project staff often disagreed 
with the actions of paramilitaries and placed themselves and/or their families at risk of harm while attempting to reduce paramilitary violence and crime.

Local residents could also be placed at risk of violence, intimidation and exclusion if they reported paramilitary activities to the State. During the participant observation, a victim of paramilitary violence approached project staff for help and this crime was reported to the police. However, paramilitary members responded to the reporting of this crime by threatening the individual and their family with violence, if they continued to pursue this case through the criminal justice system. When project staff became aware of these threats, they informed the individual as they were genuinely concerned about the individual's wellbeing and that of their family. The individual considered withdrawing their case from the criminal justice system as, although they wanted the paramilitary member prosecuted, they were concerned that State officials and project staff would be unable to adequately protect them and their family from violent paramilitary retaliation. When victims and witnesses live in the same communities as paramilitary members, paramilitary members can easily identify and pose a serious, credible risk to these individuals and their families, with State officials struggling to provide adequate protection in such circumstances.

The requirement to report all known crime to the State can also pose challenges in other ways. Project staff reported that this requirement could deter offenders and their families from seeking help to reduce offending. While individuals may be willing to seek help to reduce/stop offending, it was argued that they were not willing to access this help if doing so risked prosecution. Those whose offending had resulted in threats of paramilitary punishment violence were believed to be particularly unlikely to approach the projects for help, as reporting these events to the police increased their risk of both prosecution and further violent paramilitary retaliation for informing the police of the threats against them. As a result, many project staff were concerned that the requirements of the protocol had reduced the willingness of offenders and their family members to approach project staff for help, reducing their ability to deal with crime and paramilitary violence. 
Furthermore, it was proposed that some local residents were reluctant to engage with the projects for ideological reasons and/or dissatisfaction/distrust of State officials. For those who continued to experience a lingering distrust/dissatisfaction with State officials, it was felt that these individuals were reluctant to engage with the projects following the projects development of closer working relationships with State agencies. Supporters of paramilitary organisations were also described as being unlikely to engage with the projects, as project staff were working with State agencies to try to reduce crime and paramilitary violence:

"Obviously it is easier for the victim to go to an armed group because all they do is go to the armed group and report it [...] now if you are a supporter of one of those groupings, why would you want [...] from their perspective why would they come to us?" (participant 33).

Accordingly, increasing State regulation and cooperation not only restricted what project staff could do but it also affected the extent to which paramilitary members and local residents were willing to cooperate with the projects. In order to be able to use restorative justice to address crime and paramilitary violence, projects not only required State approval but the cooperation of paramilitary members and local residents.

\section{Discussion}

While policy changes have enhanced the role community based restorative justice projects can play in the criminal justice system, in reality the ability of these projects to use restorative justice to tackle crime and paramilitary violence has been weakened. Policy initiatives developed to validate and legitimate the work of the projects have dampened their effectiveness by reducing the number of community referrals received and the willingness of paramilitaries to use the projects as an alternative to paramilitary punishment violence. Despite the inclusion of the projects in the criminal justice 
system, the Public Prosecution Service rarely used the projects as a restorative justice disposal, continuing to use the Youth Justice Agency instead. Consequently, while these policy changes have improved relationships between the projects and State agencies (and increased their involvement in crime prevention, community safety and diversionary activities), they are seldom allowed by the State to use restorative justice to deal with crime or paramilitary violence.

Rather than being funded to directly deal with paramilitary violence or crime, the projects are mostly funded by State agencies to provide crime prevention, community safety and diversionary activities. Indeed, in many cases it was a condition of their funding that staff do not discuss young people's criminal offences. While this may reflect a desire to avoid service duplication, there was a perception among project staff that it was also about ensuring State agency domination over responding to crime and controlling their work. Insisting that State agencies are responsible for deciding what crimes are eligible for restorative justice can undermine the ideology behind restorative justice. Restorative justice seeks to transfer responsibility for resolving crimes from State officials to those most affected by crime (i.e. victims, offenders and local communities) (Zehr 1985; Braithwaite 2002; Johnstone 2003). By creating a process which first requires State agency approval, victims, offenders and local residents could no longer decide for themselves if restorative justice was appropriate but had to wait for Public Prosecution Service approval before being given an option of restorative justice participation. Northern Ireland is not alone in adopting this policy as many jurisdictions similarly require State agencies to filter cases before giving victims, offenders and/or local communities an option to engage in restorative justice (e.g. Shapland et al. 2004; Lummer et al. 2012).

This raises questions about whose interests such policies serve and if they undermine the potential effectiveness and distinctiveness of restorative justice. In this research, policy changes were predominately introduced to reassure the public and State agencies about the credentials and methods employed by project staff. While these policy changes helped to provide greater clarity, confidence and reassurance to State officials about their interactions with the projects, it was ill-suited 
to meeting the needs of those living in the communities in which the projects were based and, in some cases, placed victims, offenders and witnesses at a greater risk of paramilitary violence. Restorative justice is supposed to empower those most affected by crime and give primacy to their needs and interests (Morris 2002). Regardless of whether State officials or community organisations deliver restorative justice, the focus on the needs of those most affected by crime tends to result in higher satisfaction levels amongst victims compared to the conventional criminal justice system (Morris, 2002). Yet, based on these research findings, policymakers were either not fully aware of how these policy changes were going to impact on those living in these communities or their needs were secondary to the government's desire to reassert their authority and control over how crime was being responded to. McEvoy and Eriksson (2008) have argued that as the communities in which these projects were based had operated their own parallel justice system during the conflict, the government was keen to reassert their authority and ensure all crime was dealt with through the criminal justice system. Requiring the projects to report all crime to the police and wait from State agency approval provided one means of achieving these objectives (McEvoy and Eriksson 2008). However, as witnessed in this research, State agency domination of this process reduced engagement, especially among those who were disenfranchised, fearful of being prosecuted and/or challenging the legitimacy of the State.

In transitional societies, State agencies can seek to incorporate the use of restorative justice into the criminal justice system in an attempt to improve their public legitimacy (Clamp 2016). In Northern Ireland, policy changes allowing the projects to act as a formal disposal in the criminal justice system demonstrated a willingness to work with local community groups to address crime, transform conflict, peace build and tackle paramilitary violence. Nonetheless, a straightforward relationship between policy and practice is not always evident, as practitioners must interpret and implement policies, sometimes resulting in significant gaps between policy rhetoric and practice (Lipsky 1980). In this case, while policy changes allowed the projects to act as a restorative justice disposal, this seldom happened and the State controlled Youth Justice Agency continued to be in charge of overseeing the 
use of restorative justice. State agencies did increase their interactions with the projects but only used services which supported their own work rather than those that acted as an alternative to State service provision. The ability of State and community based organisations to simultaneously hold cooperative and competitive relationships with each other has been identified in previous research (Corcoran and Fox 2012; Mills et al. 2012). Positive interagency collaborations can occur when services are perceived as being beneficial to State agencies, but if they compete with State services, State officials can resist referring cases to these services as they attempt to protect their own jobs and position (Rumgay and Cowan 1998; Hedderman et al. 2008; Corcorcan and Fox 2012). Research also indicates that restorative justice is more effective when used in cases of serious crime involving violence and repeat offending (Sherman and Strang, 2007; Strang et al. 2013). Yet, in Northern Ireland and many other jurisdictions, State policies only consider cases involving young people and/or low-level offending for restorative justice (Miers 2001; Beckett and Kartman 2016). As a result, how State agencies are using restorative justice has led some to express concerns that its distinctive and benevolent features are being corrupted to expand State agency control and distract from wider issues within the criminal justice system (Boyes-Watson 1999; Bazemore and Maruna 2009; Greene 2013; Wood 2015; Clamp 2016; Hoyles and Rosenblatt 2016).

In Northern Ireland, some communities continue to experience distrust and a reluctance to report crime to State officials, preferring instead to use paramilitaries to respond to criminality (Topping and Byrne 2012; NIE 2016a). While the willingness of paramilitaries to cooperate with community based restorative justice projects has always been conditional, the findings suggest that this willingness has become increasingly patchy and unreliable. The State policy requiring the projects to report all known crimes to the police has further hindered this cooperation and may actually provide some paramilitary members will an excuse to justify their reluctance to engage with the projects. The findings also demonstrate the limitations of using restorative justice to tackle paramilitary violence as paramilitaries only wished to engage under their terms and were usually unwilling to have their own behaviour challenged, threatening those that sought to hold them to 
account for their crimes with violence and intimidation. Different strategies are therefore required to reduce crime and paramilitary violence, depending on individual openness to change and the willingness of local paramilitaries to transform their organisations into one which seeks to promote inclusivity and shun violence and crime.

Current plans by the Northern Ireland government to end paramilitary crime and violence seek to tackle criminality, promote lawfulness, support transition away from paramilitary involvement and address wider systemic factors contributing to this behaviour (NIE 2016b). In these plans, the government endorses the use of restorative justice and community organisations to reduce paramilitary crime and violence, and encourages local residents to take a stand against paramilitarism by reporting crimes to the police (NIE 2016b). However, it is difficult to see how these plans will be effective when the issues identified in this research remain unaddressed. For instance, it is unrealistic to expect local residents and community organisations to report paramilitary activity without putting forward a clear plan for how State agencies will protect them and their families from violent paramilitary retaliation. Similarly, plans to provider longer term funding for the projects, create a centre for restorative excellence and involve the projects in providing programmes designed to divert young people from paramilitarism (NIE 2016a; 2016b), will not address why State officials seldom allow the projects to deal with crime or paramilitary violence, as well as why project funders stipulate that projects should not be involved in directly discussing criminal offending. The extent to which restorative justice may be a useful theoretical framework for working with paramilitaries who do not wish to engage with the projects has also not been questioned. These issues need to be addressed if the government's plans to end paramilitary crime and violence are to stand any chance of success.

While there are a number of limitations within this research, a number of recommendations can be made. Due to the small sample size, lack of paramilitary members and offenders as research participants, and the changeable and varied nature of the interactions between projects, local residents, paramilitaries and State officials, caution must be used when interpreting the 
generalisability of these findings. Nevertheless, the findings indicate that the government needs to review its policies (and how these policies are being used in practice) so that the experience of those living in communities with a strong paramilitary presence is placed at the core of these policies, ensuring policies are designed and used in a way which meets the needs of local residents rather than State officials. Indeed, local residents should be involved in revising policies and identifying service provision and support priorities, which will help reduce paramilitary involvement and allow local residents to take a stand against paramilitaries safely. Factors hindering effective interagency collaboration (e.g. competition, lack of knowledge and funding arrangements) between the projects and State agencies must also be dealt with. In addition, how and when restorative justice is being used must be reviewed to ensure that it is being applied to violent and repeat offending rather than lowlevel/youth offending (which research evidence suggests has minimal impact and contributes to netwidening), as well as when paramilitaries are willing to cooperate with the projects.

In conclusion, these findings demonstrate the potential for State policies, and State officials use of these policies, to undermine community based restorative justice initiatives and the limitations involved in using a restorative justice approach to tackle paramilitarism. They raise questions about the extent to which efforts by State agencies to control and regulate the use of restorative justice may actually undermine its ideology and potential effectiveness and can act as a warning to other transitional societies seeking to use community based restorative justice projects to tackle paramilitary crime and violence.

\section{Funding}

This work was supported by a doctoral scholarship from the Department for the Economy Northern Ireland.

\section{Acknowledgements}


We would like to thank all those who facilitated this research and provided comments on earlier drafts of this article.

\section{References}

Archick, K. (2017), Northern Ireland: Current Issues and Ongoing Challenges in the Peace Process,

Congressional Research Service.

Bazemore, G. and Maruna, S. (2009), Restorative Justice in the Reentry Context: Building New Theory and Expanding the Evidence Base, Victims \& Offenders, 4(4): 375-384.

Beckett, K. and Kartman, M. (2016) Violence, Mass Incarceration and Restorative Justice: Promising Possibilities. Washington: University of Washington.

Boyes-Watson, C. (1999), 'In the Belly of the Beast? Exploring the Dilemmas of State-Sponsored Restorative Justice', Contemporary Justice Review, 2: 261-282.

Braun, V. and Clarke, V. (2006), 'Using Thematic Analysis in Psychology', Qualitative Research in Psychology, 3/2: 77--101.

Braithwaite, J. (2002), 'Setting Standards for Restorative Justice', British Journal of Criminology, 42/3: $563--577$.

Byrne, J. and Monaghan, L. (2008), Policing Loyalist and Republican Communities: Understanding Key Issues for Local Communities and the PSNI. Institute for Conflict Research.

Campbell, C. Devlin, R. O'Mahony, D. Doak, J. Jackson, J. Corrigan. McEvoy, K. (2005), Evaluation of the Northern Ireland Youth Conference Service. Belfast: Northern Ireland Office. 
Chapman, T. (2012), 'The Problem of Community in a Justice System in Transition: The Case of Community Restorative Justice in Northern Ireland', International Criminal Law Review, 12/3: 573-588.

Chapman, T. Campbell, H. Wilson, D. McCready, P. (2016), Justice Beyond Frontiers: Restorative Approaches To Community Conflict. Ulster University.

Clamp, K. (2016), Restorative Justice in Transitional Settings. Abingdon: Routledge.

Cody, P. (2008), 'From Kneecappings Towards Peace: The Use of Intra-Community Dispute Resolution in Northern Ireland', Journal of Dispute Resolution, 1/2: 555--569.

Corcoran, M. and Fox, C. (2012), 'A Seamless Partnership? Developing Mixed Economy Interventions in a Non-Custodial Project for Women', Criminology and Criminal Justice, 13/3: 336--353.

Crawford, A. and Newburn, T. (2002), 'Recent Developments in Restorative Justice for Young People in England and Wales', British Journal of Criminology, 42/3: 476--495.

Criminal Justice System Review (2000), Review of the Criminal Justice System in Northern Ireland. Belfast: HMSO.

DOJ (2016), Court Prosecutions, Convictions and Out of Court Disposals Statistics for Northern Ireland 2015, Belfast: Northern Ireland Statistics and Research Agency.

DOJ (2013), Northern Ireland Conviction and Sentencing Statistics 2009, Belfast: Northern Ireland Statistics and Research Agency.

Ellison, G. and Smyth, J. (2000), The Crowned Harp; Policing Northern Ireland. London: Pluto press.

Eriksson, A. (2009), Justice in Transition: Community Restorative Justice in Northern Ireland. Cullompton: Willan publishing. 
Graef, R. (2001), Why Restorative Justice? Repairing the Harm Caused by Crime. London: Calouste Gulbenkian Foundation.

Greene, D. (2013), 'Repeat Performance: Is Restorative Justice Another Good Reform Gone Bad?', Contemporary Justice Review, 16(3): 359-390.

Hedderman, C., Palmer, E., Hilling, C., Gunby, C., Shelton, N. and Askari, M. (2008), Implementing Services for Women Offenders and Those 'At Risk' of Offending: Action Research with Together Women. London: Ministry of Justice.

Hoyle, C. and Rosenblatt, F. (2016), 'Looking Back to the Future: Threats to the Success of Restorative Justice in the United Kingdom', Victims \& Offenders, 11(1): 30-49.

Johnstone, G. (2003), A Restorative Justice Reader: Texts, Sources, Context. Cullompton: Willan Publishing.

Johnstone, G. and Van Ness, D. W. (2007), Handbook of Restorative Justice. Cullompton: Willan Publishing.

Knox, C. (2013), 'From the Margins to the Mainstream: Community Restorative Justice in Northern Ireland', Journal of Peacebuilding and Development, 8/2: 57--72.

Lipsky, M. (1980) Street-Level Bureaucracy: Dilemmas of the Individual in Public Services. New York: Russell Sage Foundation.

Lummer, R., Hagemann, O. and Nahrwold, M. (2012), Improving Knowledge and Practice of Restorative Justice. Kiel: Kiel University of Applied Sciences.

Marshall, T. F. (1999), Restorative Justice: An Overview. Research Development and Statistics Directorate. 
McEvoy, K. and Eriksson, A. (2008), 'Who Owns Justice?: Community, State, and the Northern Ireland Transition'; in J. Shapland, eds., Justice, Community and Civil Society: A Contested Terrain, 157-189. Cullompton: Willan Publishing.

McEvoy, K. and Mika, H. (2001), 'Policing, Punishment and Praxis: Restorative Justice and Non-violent Alternatives to Paramilitary Punishments in Northern Ireland', Policing and Society, 11:3: 359--382.

McEvoy, K. and Mika, H. (2002), 'Restorative Justice and the Critique of Informalism in Northern Ireland', British Journal of Criminology, 42/3: 534--562.

Miers, D. (2001), An International Review of Restorative Justice. Home Office, Crime Reduction Research Series Paper 10. London: Home Office.

Mika, H. (2006), Community-based Restorative Justice in Northern Ireland. Queen's University Belfast, PhD Thesis.

Mills, A., Meek, R. and Gojkovic, D. (2012), 'Partners, Guests or Competitors: Relationships between Criminal Justice and Third Sector Staff in Prisons', Probation Journal, 59/4: 391--405.

Monaghan, R. (2010), 'An Imperfect Peace': Paramilitary Punishments in Northern Ireland', Terrorism and Political Violence, 16/3: 439--461.

Morris, A. (2002), 'Critiquing the Critics: A Brief Response to Critics of Restorative Justice', British Journal of Criminology, 42/3: 596--615.

NIE (2016a), The Fresh Start Panel Report on the Disbandment of Paramilitary Groups in Northern Ireland. Northern Ireland Executive.

NIE (2016b), A Fresh Start: The Stormont Agreement and Implementation Plan'. Northern Ireland Executive.

NIO (2007), Protocol for Community-based Restorative Justice Schemes. Northern Ireland Office. 
NIO (2015), Assessment on Paramilitary Groups in Northern Ireland. Northern Ireland Office.

O’Dwyer, K. and Payne, B. (2012), 'Restorative justice', In D. Healy, C. Hamilton, Y. Daly, M. Butler, eds., The Routledge Handbook of Irish Criminology, 222--241. London: Routledge

PSNI (2016), Police Recorded Security Situation Statistics Annual Report covering the period 1st April 2015-31st March 2016. PSNI.

Rumgay, J. and Cowan, S. (1998), 'Pitfalls and Prospects in Partnership: Probation Programmes for Substance Misusing Offenders', Howard Journal of Criminal Justice, 37/2: 124--126.

Shapland, J., Atkinson, A., Colledge, E., Dignan, J., Howes, M., Johnstone, J., Pennant, R., Robinson, G. and Sorsby, A. (2004) Implementing Restorative Justice Schemes (Crime Reduction Programme): A Report on the First Year. Home Office Online Report 32/04. London: Home Office.

Sherman, L. and Strang, H. (2007), Restorative Justice: The Evidence. London: The Smith Institute.

Strang, H., Sherman, L., Mayo-Wilson, E., Woods D. and Ariel, B. (2013), 'Restorative Justice Conferencing (RIC) Using Face-to-face Meetings of Offenders and Victims: Effects on Offender Recidivism and Victim Satisfaction. A Systematic Review', Campbell Systematic Reviews, 9(12): 1-59.

Shirlow, P. and McEvoy, K. (2008), Beyond the Wire: Former Prisoners and Conflict Transformation in Northern Ireland. Pluto Press.

Tonge, J. (2014), 'A Campaign without End: Dissident Republican Violence in Northern Ireland', Political Insight, 5/1: 14---17.

Topping, J. and Byrne, J. (2012), 'Paramilitary Punishments in Belfast: Policing Beneath the Peace', Behavioural Sciences of Terrorism and Political Aggression, 4(1): 41-59.

Van Ness, D. and Strong, K, H. (1997), Restoring Justice. Cincinnati: Anderson Publishing Company. 
Walters, M.A. (2014), Hate Crime and Restorative Justice: Exploring Causes, Repairing Harm. Oxford: Oxford University Press.

Winston, T. (1997), 'Alternatives to Punishment Beatings and Shootings in a Loyalist Community in Belfast', Critical Criminology, 8/1: 122--128.

Wood, W. (2015), 'Why Restorative Justice Will Not Reduce Incarceration', The British Journal of Criminology, 15(5): 883-900.

Zehr, H. (1985), 'Retributive Justice, Restorative Justice', in G. Johnstone, eds., A Restorative Justice Reader: Texts, Sources, Context, 69--82. Willan Publishing. 